\title{
Fragmentos de uma genealogia de mulheres no contexto prisional: um estudo de narrativas sobre a experiência de aprisionamento
}

\author{
Jaqueline Carvalho Quadrado \\ Orientadora: Prof.a Dr. ‥ Lourdes Maria Bandeira \\ Curso: Doutorado em Sociologia \\ Data da defesa: 31.01.2014
}

$\mathrm{N}$ a tese busco, por meio de uma genealogia, problematizar as relações entre as experiências prisionais e a constituição de processos de subjetivação. O estudo das experiências prisionais e de suas implicações na conformação de subjetividades é instrumentalizado, principalmente, sob duas ferramentas de análise formuladas em estudos genealógicos de Foucault: o poder e o saber. Assim, esta pesquisa analisou as narrativas autobiográficas de mulheres presas na Unidade Prisional Feminina de Palmas (TO), com recorte temporal de 2010 a 2012. Analisou-se como se configuram os campos de experiências e as condições que marcam a emergência dos discursos/verdades que sustentam os processos de subjetivação da mulher presa/ criminosa. O objetivo é compreender as experiências de aprisionamento dessas muIheres autoras de crimes, buscando, por meio de suas narrativas, fragmentos de suas experiências passadas - anteriores à prisão, envolvidas ou não na criminalidade -, e no presente, as estratégias de sobrevivência e resistências, inscritas no cotidiano, nas atividades, nos sentimentos, nas formas de controle e nas relações sociais construídas e vivenciadas por elas na prisão. As primeiras sínteses informam existir poucas diferenças entre essas várias mulheres, no que diz respeito ao mundo vivido, às condições socioeconômicas, às experiências culturais, sexual-amorosas, educativas e de trabaIho. As experiências prisionais, nos aspectos subjetivos, também se assemelharam, no plano do coletivo, ainda quando possam ter se diferenciado nas especificidades do sujeito. Também possibilitou a elucidação das principais marcas dos seus desenvolvimentos biográficos: a combinação de fases - a construção de uma família, o exercício de uma profissão e a formação/educação -, as rupturas, as transições, as continuidades e descontinuidades, todas arraigadas em seus mundos de ação concretos. As narrativas denunciam a trajetória de sofrimento precoce e contínuo associada às con- 
dições de classe social - pobreza e trabalho precarizado -, vulnerabilidade da mulher, especialmente na relação conjugal - e questões geracionais - a difícil educação dos filhos. Soma-se a essas ausências a do Estado com sua precária e ineficiente "política de tratamento penal". Os dados revelaram ainda a capacidade dessas mulheres de usarem novos esquemas de estruturação biográfica, ligados a uma assimilação subjetiva das experiências proporcionadas - ou não - no ambiente carcerário, e com ela, a produção de um sentido biográfico próprio, ainda que associado a um espaço social imediatamente próximo.

Palavras-chave: experiências; narrativas autobiográficas; prisão; mulheres; genealogia. 